\title{
AFFIXOIDATION AS A PRODUCTIVE WAY OF WORD-BUILDING IN MODERN ENGLISH AND FRENCH
}

\section{Olena Samoilenko ${ }^{1}$}

DOI: https://doi.org/10.30525/978-9934-588-15-0-115

Abstract. The article is devoted to the problem of affixoidation in modern European languages. Under the term affixoid we understand word-building elements which have characterstic features of both affixes and word stems. The main peculiarity which usually belongs to affixes is productivity. Due to this feature affixoids help to develop new semantic and grammar categories. As affixes, affixoids can express a wide word-building category (of person, object, sign, location), they are highly productive, can perform the same word-building function. So, the object of our investigation is lexical units of intermediate status, namely those which have signs of affixes and word roots. Common compound words which have no limits in usage make up the material of the article. The choice of the material preconditioned the usage of the linguistic methods: the analysis of literature, distributional analysis, word-building analysis. The purpose of research is to prove the existence of word-building elements with intermediate status in the English language and to find out their peculiar features. The dissertation analyzes the affixoides meaning the word-building constructs of intermediate status, which have signs both of affixes, and of roots. To affix characteristics it is necessary to attribute high frequency of reproduction, a fixed position in the word and developing of certain categorical meaning. The signs of the roots include the presence of a complete lexical meaming and the possibility of usage in different word-building samples. The study proposes affixoid classification by their origin. In the Russian language there are borrowed, native and international affixoides. The last group of word-formation elements has been the most studied recently, because their presence is observed in many modern languages, so they are analyzed in detail on the material of different language systems. But even the presence of a large number of words with

\footnotetext{
${ }^{1}$ Candidate of Philological Sciences,

Head of the Department of Linguistic and Humanitarian Subjects,

Donetsk National Medical University, Ukraine
}

(C) Olena Samoilenko 
the term-elements of Greco-Latin origin, does not contribute to solving one of the central problems of modern terminology - the question of the status of such formants.

\section{Introduction}

Recently compounding has become not only the main way of creating new words, but also a very important and productive source of new derivative elements. This phenomenon can be explained by the fact that word-formation of modern languages is characterized by the tendency to make up new compound words by analogy, according to the patterns which have already been existing in language systems. Moreover, word formation by analogy, according to some scholars, is leading in the creation of terminological.

So, in modern languages it is possible to observe the tendency to economizing language efforts: instead of phrases and word-combinations we use compound words which are built according to the models which are characterized by a high degree of productivity in languages. New words are created not on the basis of the unit of the syntactical level in the language, but by adding some repeating component which has some semantic meaning. Very often in such cases elements in pre-position and elements in post-position develop functions of affixes (for example, classifying and generalizing). These elements may be called affixoids (similar to affixes). The great amount of such units preconditions the topicality of this work and its aim - to reveal the volume of this term and to work out possible principles of classification.

The relevance of the work may be explained by the fact that the problem of affixoidation has not been analyzed in the linguistic literature. It is very important to define the volume of the term "affixoid", to work out possible principles of classification and typology.

Another important question is preconditioned by the possible semantic changes if we compare independent root morphemes and components of compound words.

The problem of affixoids and affixoidation as a peculiar linguistic process is worth discussing and analyzing, because modern European languages are characterized by a great number of such word-constructing elements.

The material of the paper includes literal widely-spread every day words. These lexical units are analyzed by using the methods of distributional analysis, word-building analysis and analyses of existing linguistic resources. 


\section{History of the term}

In the 1950s M.D Stepanova proposed the term "semi-affixation" for root morphemes, which regularly participate in word-forming processes and do not lose any formal or semantic connection with the corresponding root. They:

- denote, like affixes, a broad word-forming category (persons, objects, characteristics etc.);

- they are high productive, often participate in creating new words;

- can compete with "real" affixes as for realizing their primary function [12].

Other researchers (N.F. Klimenko) [4] consider such elements to be root morphemes . In general, up to present time, linguists have not yet agreed on the definition of the linguistic status of such components: they are called affixoids (K.H.Horodenskaya), relatively free/relatively bound morphemes (O.O. Kubriakova), affixed bases (M.M. Shansky), bound supporting components (V.V. Lopatin), international terminological elements (V.G. Hrigoriev), semi-affixes (G.B. Antrushina), combining forms, subaffiixes. According to R. Safin, such morphological units are: 1) bound morphemes ofspecial type; 2) used only in conjunction with other affix or root components; 3)have individual lexical meaning; 4) capable of acquiring the generalizable meaning which is similar to the categorizing meaning of affixes. We support the view that such elements have the status of an affixoid, since the composites they include cannot be deployed in a phrase. In addition, these components have a generic lexical meaning: something related to water (hydrophobia. hydrology, hydropark), modern informational technology etc. Thus, such entities have the status of prefixes in the preposition and the status of affixoids in the postposition. R. Safin considers the above-mentioned units to be transitional type morphemes. They function both as roots and affixal morphemes [10].

There is also an alternative approach to the problem of semi-affix / affixoid definition. For example, the German scientist W. Henzen talks about other components of compound words that "threaten" to become suffixes and refers to them elements -werk, -zeug, -voll, arm etc., considering them in the suffix section sometimes called "components in functions of word-building items" [19, p. 170-171, p. 194-195]. Other German linguists G. Becker and F. Kluge writes of such elements of compound words as about suffixes. 
J. Nesfield calls the finite component of compound words capable of combining with different bases a "suffixed word". The scholar mentions that such morphemes have the following characteristic features: a) "suffixed word" joins other words so often that a whole series of words are formed, while the regular component stands can be used separately; b) most of the words that are suffixed do not fully express the meaning they have when when they are used separately [22, p. 391].

O.O. Selivanova understands a syncretic in place and role word morpheme, intermediate between root and service morphemes, a former root morpheme that has lost its motivational role in the semantic word and received signs of service morpheme under the term "affixoid".

In the 90s of the twentieth century, Yu. A. Zatsny also touched upon the problem of alternative word-building, using the term a "pseudo-compound" word [3, p. 11]. Under this term, this researcher understands a compound word, a part of which stands out as a result of the creation of a whole series of innovations, incorporates the semantics of the whole initial model. For example, $\mathrm{n}$ the word "blackmail" the semantics of the second element in the word from the wor has been changed, and new neologisms such as greenmail and greymail appear (they mean a specific kind of blackmail that is common in the modern business world when buying a large block of shares of a particular company, which is subsequently resold to owners ofthe same company, but with a big twist in exchange for a promise to have no claim to control this company). The suffixoid -gate in the sense of "scandal, especially political" arose from the formation of a large number of neologisms by analogy with the word Watergate, which became a symbol of political scandals (donorgate, Irangate, travelgate, Trumpgate, Ukrainegate). To describe affixoids, the scientist uses the term "semi-affixation".

After studying and generalizing the basic characteristics of semi-affixes, which were described by M.D. Stepanova, G.Paul, O.S. Kubryakova, we can conclude about functional synonymy between affixes and affixoids. As an example, the English component - -like, whose meaning is almost exactly the same as themeaning of the true suffix $-l y$. So, there are adjectives with -ly and -like with the same meaning, for example: gentlemanlike and gentlemanly (honest, decent; polite); manlike and manly and others.

In modern linguistic literature, affixoid is defined as an intermediate morphemic part of a complex or compound word, which is mostly cor- 
related with a full word or base and is repeated with the same meaning in a number of words and approaches in its word-forming function (ability to form a new word) to a real affix. As significant parts of the word affixoids are observed only within the complex words and only as morphemes, which can equally be used both as parts of compound words and as roots [15]. N.F. Klimenko believes that the concept of affixoid should be referred to components of complex derivatives that are capable of forming the same series of words, but have not undergone either partial or complete desemantization, that is, they are actually roots. In other words, there are two main semantic attributes of affixoids: 1) the loss of a specific lexical meaning, 2 ) the acquisition of a new, generalizing meaning and, as a consequence, the formation of word-forming series: fr. autodrome - cosmodrome -aviadrome, eng. black-free-tax-free - trouble-free-cruelty-free.

\section{Different approaches to the term "quasi-composite"}

O.O. Selivanova suggests the term quasi-composite, which means words of intermediate status that, by their nominative nature, were formed by composition, but on the other hand, are characterized by the weakened or absent motivational role of one of the root morphemes, which turned into affixoids, or roots that have lost semantic connection with the meaning of the whole word [Selivanov Encycle]. The second element of such units is a basis, but it serves as a suffix, that is, serves to form new words by analogy, for example, waterproof-kissproof-foolproof: if there is something that protects against water, then you can talk about an object that will protect against kisses or fools. G.B. Antrushina calls such components of compound words semi-affixes, that is, elements that, on the one hand, have all the characteristics of an independent basis, but on the other hand, due to the frequent use of their meanings, become very generalized, that brings them closer to suffix. It is the law of similar use that transforms meaningful words into affixoids.

But the problem is that, on one hand, it does not have a generally accepted term for designation of such units which have syncretic character. And, on one hand, researchers, who use the same term (pseudocomposites), mean different things. H.Marchand offers the term pseudo-composites, which means borrowings that are motivated by popular etymologization, when instead of a simple foreign lexeme, people use a combination of 
several non-borrowed words which sound similar to a new, strange lexical unit. For example, in English, there is the word sparrowgrass which is used as the equivalent of the Latin word asparagus, crayfish instead of French crevice. The same meaning of the term "pseudo-composites" is supported by I.V. Arnold. Under the term pseudo-compounds H. Marchand also understands verbs formed not by word-compounding, but by conversion and reverse derivation: to proof-read, to vacuum-clean, to hitch-hike, as well as rhyming composites: helter -skelter. As you can see, even one and the same researcher can understand phenomena quite different in nature under one and the same term: phonetic imitations related to the process of borrowing, reduplication and back-formation.

S.S. Hidekel interprets the term "pseudocomposites" in a quite different way, which juxtaposes proper compound words and compound derivatives, and to the first he refers only such complex units, both components of which can function as independent words (baby-sitter, street-fighting). In contrast to complex words, formations such as long-legged are considered to be affixed derivatives.

A similar theory for the French language is developed by A. Mitterrand, who also suggests that not all the compound words can be called "pure" composites, so he divides this large layer of compound words into proper compounds and recomposites. According to this linguist, recomposites are characterized by the fact that one of the components of Latin or Greek origin does not exist in the language in the isolated form. As an example, the linguist refers words with the initial components néo-, contre-, télé-, radio-, crypto-, anthripo-, proto, thermo-, multi-, mono-, macro- (néo-vitalisme, néo-positivisme, téléspectateur, télépointage, radioporter, cryptogramme, anthropocentrisme, thermonucléaire, multitube, monolthique, macrocosmique) and final constituents -théque, -crate-cratie, -gramme, -logue-logie, -phile (politologie, phénoménologé, socioémérémé, cinémigémérémie, technocratie) to the group of recomposites [21].

In general, there are three main approaches to interpreting the nature of this linguistic phenomenon:

1. the first steps in the study of this phenomenon were made by M.D. Stepanova, who made her research on the material of the German language. It was she who proposed the term "semi-affixes" to refer to the word-formants of the -mann type, which gradually loses their semantic connection 
with their lexical source. The researcher, therefore, considers the functioning of "semi-affixes" as an intermediate stage in the transition of roots into affixes, and the very units themselves as syncretic elements (constructions that have a dual nature, namely the shape of the root and the function of the affix);

2. It would be a mistake to believe that all scholars immediately recognized this linguistic phenomenon. K.V. Levkivska denied the theory of semi-suffixes (as well as the theory of pseudocompound words) [6] and emphasized that high frequency of usage is not yet a reason for the transition of roots into the status of suffixes, especially since most native speakers clearly determine for themselves the presence in compound words of two bases, but not the basis and suffix.

3. E.S Dyachkova regards semi-affixation in English as an independent, separate way of word-formation (rather than a special kind of word-composition), which is characterized by a certain set of specific features [2]. The basis for this hypothesis is the presence of a large number of words with semi-suffixes in English, as well as the syncretic nature of the word-forming elements considered within some compound words. In our opinion, the researcher points to the marginality of certain constituents in the language, so she has no reason for distinguishing semi-afffixation as a particular way of word formation, but she simply emphasizes its syncretic nature.

Thus, affixoids are linguistic units of a transitional type in which signs of both roots and affioxes are observed.

The affixal features of affixoids include regularity of reproduction: English affixoid -like is observed in 52 words [9]: affix-like, angel-like, animal-like, baby-like, beast-like, business-like, cat-like and more. In French, a large number of suffixes with the suffixoid clé can be noted, and not all of them are fixed by dictionaries, but occur in speech to indicate a certain important reality: temoin-clé, personnalité-clé, position-clé, action-clé, role-clé, function-clé, importance-clé, procedure-clé, figure-clé, center-clé, ville-clé, region-clé, moment-clé, pays-clé, partie-clé, texte-clé etc.

The main feature of affixoids is their correlation with the original roots of meaningful words, but the degree of this connection may be different. It is this feature that can becomew the basis for the classification of affixoids. 


\section{Principles of classification of affixoids}

An attempt to classify affixoids by the degree of connection with the basis is made by $V$.Yu. Ryazanov He believes that semi-fixes are morphemes that are at the transitional stage on the way to converting root morphemes into affixes [9]. This definition of affixoid is rational, because some modern productive suffixes are the result of the transition of ancient roots (namely the second elements of compound words) to the status of suffixes. For example, the ancient German -skapi is present in modern English in the form of the suffix -ship, and in German -schaft.

V. Yu. Ryazanov developed the classification of English semi-affixes on the basis that not all components that repeat and make up long word-forming series have an equal degree of "affinity" to affixes. The reason for referring semi-affixes to a separate group of word-building elements is the ability of the word-forming components to connect with a large number of different root morphemes and keep generalized lexical meaning [9]. The researcher divides 30 English word-forming elements into 4 groups according to the degree of their approximation to affixed morphemes.

The first group includes 8 components that are most closely related to true affixes: -man, -happy, -like, -free, -wide, -head, -well, and -ill. In these affixoids the connection with the original lexical element is almost lost: analysis of word-forming series proves that the meaning of these word-forming constructs is significantly different from the meanings of the lexemes with which they are correlated. Important is the fact that all the above-mentioned components in all new words always have the same abstract meaning. A vivid example of the loss of primary lexical meaning is the -happy element, which, as an affixoid, develops the following meaning "obsessed with what is indicated in the first component": hump-happy, hate-happy (in anger), heat-happy, hobby-happy (obsessed with some hobby), footlight-happy (mixed in the theater), headline-happy (very nutty), power-happy (intoxicated by power). The-like element acquires the meaning "similar to that which is denoted by the first component", and there is a shift from the meaning of "similarity" to the qualitative characteristic of belonging to some group or type: slave-like, baby-like, beast-like, younglike, fairly-like, lady-like. The element -free in the post-position acquires a general abstract meaning: "one that does not contain a specific ingredient or characteristic (mostly negative) and demonstrates a word-like proximity 
to the productive suffix -less (without something): alcohol-free, cholesterol-free, corn-free, dairy-free, tax-free, carefree, trouble-free (reliable), milk-free. The element -wide has the generic meaning "spread over a certain territory, designated by the first component". It is possible to observe the contradictions between the meaning of the word wide when used individually and its semantics the "infinity" of the first and the "limited" of the second: campus-wide (common across the university or college), continent-wide (the one used in the whole continent), worldwide, society-wide, population-wide. The meaning of the -head in the post-position has changed a lot compared to the meaning of the word head (part of the body), as a postpositional affixoid it functions as an agent suffix that forms compound words with a negative connotation such as acidhead (a person who regularly uses LSD), cokehead (aperson who regularly uses cocaine), crackhead (a crack addict), cubehead (LSD addict), hashhead (cannabis smoker). In some formations, the affixoid -head is used in a metaphorical meaning to construct new lexical units with the meaning "fool, dumb": airhead, beef-head, blockhead, bubble-head etc. As we can see, at the base of each word-making value of an affoxide is a certain value of the original basis. The semantic connection to it is stronger if the affixoid correlates with the primary, central meaning of the corresponding basis, and weaker if the affixoid correlates with its peripheral meaning.

The constructs of well- and -ill are distant from the independent words that correlate with them. These affixoids make up semantic rows in which well - is used to indicate a positive evaluation of what is determined by a component in a postposition, and ill-with an abstract meaning of incompleteness or bad quality of what is determined by a second component: well-advised, well-affected well-becoming (correct), well-conducted (educated, tactful), ill-conceived, ill-considered ill-defined, ill-fitted, ill-found, ill-founded. If we speak about the affixoid -man in the words snowman, rainman, iceman (the killer) the primary lexical meaning "man, man" is already completely lost.

The loss of the primary lexical meaning is characteristic of the description of the French word-building element-homme (bonhomme), German -mann. It is interesting to note that in Russian and Ukrainian languages "человек, чоловік" are not affixoids. On the other hand, borrowed English word-formant - man became widely used in modern Slavic and French languages: Ukr. бізнемен, спортсмен, fr. sportsman, businessman. 
The group of affixoids that are closest in nature to affixes are international termonological elements, because the semantic connection of such components to the their source (Latin or Greek) is gradually disappearing: avia-, hydro, aqua, -logy, -scope, -graphy, mini-/ mini-, maxi-/ maxi-, retro-, geo-, zoo-, bio-, aero-, auto-, agro, -phone, -drome, -cracy.

V. Ryazanov refer components -buster, -person, -boy, -looking, -intensive, -rich, -proof, -friendly, -minded, -speak, -hop, -worthy to the second group. According to the researcher, they have not yet completely lost their primary lexical meaning, but during semantic analysis there is a certain change in the meanings of the components in comparison with independent words. The -buster construct, although it retains some of the semantics of destroying, but is used in units as an agent suffix and perform the function of the suffix -er: city-buster (atomic bomb), keister-buster (person who breaks safes), bridge-buster, cop-buster (killer of policemen), door-buster (apartment thief), omni-buster (bus thief). It is interesting to see examples where the units containing this word-building element lose their negative connotation because of the negative meaning of the first component: crime-buster, sin-buster. In some cases, the word-building buster loses its negative semantics: bronze-buster (sculptor), cloud-buster (ball that flies high in baseball). In our opinion, we can talk about metaphorization and the development of a new meaning "conquest, victory in the fight". The elements - person and -boy act as agent suffixes, but in the first case, there is a lack of gender differentiation, which is particularly relevant in today's English-speaking society with a steady tendency to fight gender discrimination: barperson, counterperson, spokesperson, statesperson, chairperson, chairperson of the meeting, delegation. When creating words with a suffixoid -boy the age is emphasised: busboy (assistant waiter), cabin-boy (jungle), chore-boy (farm assistant), errand -boy (courier boy). As the second component of compound words, the element -looking has changed its semantics and has a more generalized character compared to the meaning of the independent word "looking": European-looking, trim-looking, young-looking, bilious-looking, frail-looking (weak, painful in appearance), good-looking (with good and pleasant appearance).

The word-components -intensive and -rich have partially lost their semantical meanings and become close to the suffix -ful in function. The word-building element -intensive develops the meaning "the one that con- 
tains a large number of components defined by the first element of a compound word", which retains the connection with the adjective intensive (careful, rough), but is still different in terms of quantaty: disc-intensive (which takes up a lot of hard disk space), steel-intensive, data-intensive ( the one that requires a lot of information processing). The same characteristics may be given to the component -rich, which, unlike the independent word with the lexical meaning "wealthy", acquires the meaning of "high degree of concentration of a certain substance": carbon-rich (with high concentration of carbon), fat-rich (with high concentration of fats) ), lead-rich, asset-rich, resource-rich. The word-forming element -proof in the post-position develops the meaning "protected, usable under the conditions specified in the first component of the word" (compare with the meaning of the independent word "strong, impenetrable, stable"): audience-proof, wrinkle-proof fabric etc. The element -friendly also undergoes some desemantization: instead of the meaning of the word "friendly, benevolent", the new semantic meaning "educated, prepared for the convenience and benefit of whoever or who defines the first component" has appeared: environment-friendly, ozone-friendly ( harmless to the ozone layer of the atmosphere), Earth-friendly, reader-friendly (useful for the reader (about summaries, footnotes, etc.)), listener-friendly (easy and enjoyable to listen to). The meaning of the word-forming element -minded is characterized by the semantic shift in comparison with the meaning of the independent word minded "ready to do someything". This construct points mostly to a person's mental activity, outlook, and interests, such as civic-minded, high-minded (1) noble, generous, 2) arrogant, feeble-minded, dumb, dumb, retarded ), reform-minded (with reformist views). The peculiarity of the word-formant -speak is that while speak is a verb with the basic lexical meaning to talk, in postposition it forms nouns with a common meaning of "specific language, jargon, which characterizes a certain person, group, style": sportspeak (language of sports journalists and commentators), teacher-speak (professional vocabulary of teachers), media-speak (jargon of specialists in the field of media). The word-building element -hop makes up a group of lexical units with the same general meaning "frequently changing location, place of work, living conditions, etc.". The meaning of this affixoid is semantically different from the isolated word hop (to leap); it has abstracted meaning based on metaphorical associations, such as barhop, boutique-hop, booth- 
hop (kiosks, tents), galaxy-hop, island-hop. The word-building element -worthy becomes "worthy of something which is mentioned in the first component": applause-worthy, award-worthy, ear-worthy, praise-worthy, headline-worthy, newsworthy (interesting). As we can see, the meaning of the word-building element does not differ much from the meaning of the basis from which it derives: "deserving something".

The third group includes the components -type, -style, much-, near, mock-, big-, new-. They are quite remote from the real affixes because of the limited combinatorics and scope, and the semantic relation of these constructs to the corresponding basis is clearly seen. For example, -type and -style formants are used to refer to phenomena that are of a particular type or style, similar to something: their meaning may coincide with the meaning of the corresponding isolated word: ballon-type, church-type, discussion-type, horse-drawn-type, hospital-type, hospital-type, police-type, European-style, French-style, antique-style.

The meaning of the formant $m u c h$ - is more closely related to the definition of the phrase "a lot of, plenty of", but acquires some abstract meaning of the degree of action or quality - "the one with a high degree of quality described by the component in the postposition": much-admired, much-appreciated, much-beloved, much-complimented. It is also necessary to pay attention to the similarity of the word-forming construct much- and the prefix multi-, which expresses the meaning "many"for objects that can be counted. The word-building element near-does not also undergo significant changes in the semantics, being close in meaning to the isolated word near "close, almost all" and developing the meaning "one that does not fully correspond to the qualities required": near-beer, near-crisis, near-panic. The peculiarity of the element mock is that, as an affixoid, it loses its negative semantic coloring "false, fake, implausible" and becomes "one that imitates a particular phenomenon or process": mock-attack, mock-fight, mock-heroic (pseudo-heroic, usually characterizing a certain kind of poetry that uses exaggeration to create a satirical / ironic effect), mock-cream (cream of powdered milk, margarine and sugar), mock-duck (a piece of crispy pork made with sage and apples). The components new- and big- have also undergone partial desemantization: they maintain close relationship with the corresponding independent lexical unit with the meaning "just appeared", "large": new-age (modern, characteristic of a new generation), new-born 
(recently born), new-come. The meaning of the construct big "significant, important" implies the idea of significance but not the one of size: big-apple (the biggest, most important part), bigcasino (the main stage), big-education (education system).

And, finally, the most distant from the real affixes are word-building components work-, -based and -made, the characteristics of which meet the basic criteria for attributing repetitive components to the category of semi-affixes, since desemantization is not observed in these cases. The meanings of these elements completely correspondent the meaning of the $c$ independent words "work", "built on certain principles".

In our opinion, the above-mentioned classification needs some clarification. First, it remains unclear why in this classification the author forgets about widely accepted used affixoids, such as -gate, -berry, -land, -ware, -monger, -book, -wise, -box, which are very productive in English (for example, there are about 40lexical units with the word-building element -monger (warmonger, fishmonger, newsmonger, whoremonger), which is actively used to create occasional units and in slang. Second, it is very difficult to agree that the constructs big-, work-, -made, -looking, and -based are semi-affixes. If we turn to the element big, then its linguistic status is doubtful, because it is quite possible that it is not part of a compound word, but an independent root that acts as a member of the attributive phrase. We believe that there are no grounds to consider the components of the complex words -made, -looking, and-based as affixoids / semi-affixes, because there is a vivid connection with certain phrases such as old-looking = looking old, city-based = based in the city, Chinese-made = made by Chinese. Thirdly, in our opinion, it is not correct to unite into one group of affixoids / semi-affixes the elements -buster, -person, -proof, -hop, -friendly, which undego considerable desemantization, with the affixoid -worthy, which almost retains its primary lexical meaning.

B.I. Bartkov [1] suggests his own classification of English word-building elements. The linguist uses both the term "suffixoid" and the term "semi-affix", and puts different meanings into these terms. The researcher figures out four stages of development of English word-forming elements on the way of their transformation into suffixes:

1. Actually compound words. The linguist has counted that sometimes $10-15$ words are formed with the same finite constituent, such as -legger, 
-hide, -herd, -lore, -shoe. Due to the low productivity of models with such word-forming formants, the desemantization of the finite element is not observed and the suffix valence is zero.

2. Suffixoids. Suffixoids are characterized by high diachronic performance (30-70 words), high synchronous performance, a certain degree of desemantization and the presence of suffix valence. B.I. Bartkov refers the elements -smith, -wright, -tight, -ware, -box, -book, -yard to this group.

3. Semisuffixes. In word-forming formats-monger, -land, -berry we can observe a significant change in the semantics of the word-forming element, there is high synchronic and diachronic (100-200 words) valence.

4. Suffixes. The suffixes themselves are characterized by increased diachronic performance (300-400 words), resulting in native speakers perceiving-proof, -wise, -ship, -man elements as suffixes, using them freely in new acts of word formation.

This classification provokes a number of questions. First, the reason why the researcher considers "semi-affixes" more "suffixed" formants than "suffixoids" is unclear. From the etymological and semantic point of view there is no reason for this, especially since in modern linguistic literature these terms are used in a synonymic way. Secondly, it is rather contradictory to combine the elements - proof, -wise, -man into one class with the suffix -ship, which is used to form abstract nouns and has nothing to do with the homonymic word ship used to designate a boat. At the same time, one cannot ignore the fact that the elements -proof and -man still retain some connection with the corresponding words, at least in some of their lexical meanings. For example, the element -man is often used to refer to professions, activities, and occupations of certain people: its meaning is the same as the basic meaning of the word man - "person", that is, semantic connections are not always difficult to notice. But it should be noted that B.I.Bartkov was not the only one who considered the element -man to be an affix. P.M. Karashchuk keeps to the same the same theory and believes that -man is a suffix that retains the lexical features of the word man.

Thus, it should be noted that there is still no unity in the question of which units should be referred to affixoids. For example, J. Nesfield [221] refers to the number of suffixes (suffixed words) the following word-building elements: -guard, -son, -right, -wise, -monger, -like, -monger, -like, -man, -craft, - ward. H.Marchand thinks that only -like, -worthy, -monger, 
-way, -ways, -wise belong to the number of affix-like root morphemes [19]. I.V. Arnold adds - man, -berry, -land, -proof, -wright to this list.

Turning to the French language, Jean Du Bois states that in modern French, some meaningful words (namely, nouns) have become - or are on the way to - suffixes. To such lexical phenomena the researcher refers the word-building elements clé, pilote in formations like position-clé, classe-pilote, and in special technical terminology - constructs moteur, réacteur. The use of a particular pattern makes the linguist refer such words as turboréacteur, statoréacteur are simple in their structure and the element - réacteur is a suffix. According to J. Dubois, the syntagmatic role of the element réacteur coincides with the role of the elements -ificateur, -ateur, or even -euse - they perform the word-forming role of suffixes and are significantly different from identical independent words. The researcher completely misses the stage of affixoids and considers words with similar repetetive elements simple. A similar hypothesis can be found in the works of L.Hilber and P. Gilbert, who also believe that the components of the compound words choc, clé, pilote have evolved or are on the way of converting into suffixes.

V.P. Motashko suggests, as hypothesis, that the usage of such components does not lead to creating of compound, affixal words, or word combinations, but units characterized by their own status in a language that the researcher defines as intermediate or indefinite [8, p. 62]. It is difficult to disagree with this statement if we remember the opinion that is common in modern linguistics that the natural word-formation process in all languages develops in the direction of: sentence - phrase - word. There is an assumption that the intermediate chains can be located anywhere along this path. According to V.P. Motashko, "the morpheme can remain intermediate (neither root and nor affixal) until sufficient quantitative and qualitative features are accumulated that will lead to its own denial, thus transforming it into a fundamentally new quality" [8, p. 62].

N. M. Malkina and N. A. Shigarevskaya share another point of view. These linguists regard the second component as transforming the noun into an adjective and attempt to prove the morphological independence of the components that make up such words by considering them to be free phrases. And the constructs of compound words containing the above-mentioned elements are considered to be complete words, not formal analogues of words. 
These elements should be attributed to the class of affixoids, since they have not yet lost their primary lexical meaning. French affixoids also include type, modèle, vedette, standard, limite, plafond, record, éclair, choc, drapeau, phare, miracle, témoin, charnière, fleuve, plancher, marathon that are highly productive in realizing the word-building model "noun + noun": atelier-pilote, industrie-pilote, grève-pilote (pilot meaning "leading, advanced"), texte-clé, poste-clé, figure-clé, question-clé, problem-clé ( the element clé develops the meaning "important, significant"), question-choc, régime-choc, prix-choc (the element in the postposition has the meaning "shocking, extremely strange"), ville-type, situation-type, reponse-type (the element type means "similar"), arme-miracle, usine-miracle, remède-miracle (the conctituent in the postposition means "wonderful, miraculous"), magasin-témoin, appartement-témoin, lampe-témoin (noun témoin has the meaning "observing"), saut-record, niveau-record, moyenne-record (the post-position element develops the meaning "best, highest"), événement-phare, livre-phare, personalité-phare (the element phare that is translated as "lighthouse, headlamp" develops the meaning "important, significant"), enquête-éclair, grève-éclair, funérailles-éclair (the basis éclair with the meaning " lightning" becomes "unexpected "), âge-charnière, zone-charnière, rôle-charnière (the post-positional element develops the meaning "movable, mobile"), texte-fleuve, voyage-fleuve, procèsfleuve (the primary meaning of the base fleuve - river, and the suffixoid develops meaning "long, fluid"), cas-limite, film-limite, prix-limite (limite means "extreme, limited"), prix-plafond, niveau-plafond, salaire-plafond (the element plafond (literal translation "ceiling") develops the meaning "highest possible, highest available"), match-marathon, examen-marathon, séance-marahon (marathon means "very long"), prix-plancher, tariff-plancher (the element plancher $\mathrm{t}$ with the meaning floor develops the meaning the "lowest possible".

E.S. Dyachkova analyses "semi-suffixes" in terms of their place in the word-forming chain. She proposes to attribute to the nuclear zone proper "semi-suffixes", that is, word-forming units that have arisen on the basis of a simple root morpheme, to the nucleus zone - connecting forms (root morphemes of Greek and Latin origin), and to the periphery - derived basics and elemental bases and body elements words (-aholic: workaholic, shopaholic) [2]. 
Affixoids are linguistic word-formants that have the characteristics of both roots and bases and affixes. Summarizing the above-mentioned approaches to the definition of affixoid / semi-affix, we can conclude that the main criteria for the selection of affixoids are:

1. Repition a specific component in a large number of units. To prove this thesis, we turn to the international affixoid mania with the meaning "unhealthy attraction, obsession": aboulomania (pathological inability to make a decision), capnomania (addiction to smoking), catapedamania (abnormal interest in high jumps), cheromania (constant attraction to entertainment, fun), chionomania (constant desire to see snow), choreomania (obsession with tank), chrematomania (obsession with money), chronomania (obsession with time), cingulomania (men have a strong desire to hug a woman), clinomania (desire to stay in bed), cremnomania (obsession with mountains and rocks am), cresomania (dream of having a big pile of money), cynomania (excessive love for dogs), cytheromania (synonym for nymphomania), francomania (obsession with all french), fumimania (smoking addiction), gallomania (affection for all french), gamomania (desire to make extravagant offers to marry), Grecomania (admiring all Greek), gymnogynomania (desire to spy on other people when they are undressed), gynonudomania (the desire to rip clothes off a woman), habromania (desire to constantly have fun), hedonomania (constant pursuit of pleasure), heliomania (desire to be under the sun all the time), hellenomania (fascination with Greece and Greeks)), hematomania (blood obsession), heroinomania (heroin addiction), hieromania (pathological hallucinations on religious basis), hippomania (obsession with horseback riding), hodomania (desire to travel), homicidomania (murder mania), hydromania (irrational attraction to water), hylomania (passion for the material side of life), hyperpolysyllabicomania (excessive love for pathetic expressions), ichthyomania (excessive passion for fish), iconomania (excessive love for images of God and the saints), idolomania (the urge to create their own idols), internetomania, Italomania (fascination with Italy and all Italian), Japanomania, kathisomania (desire to sit down), klazomania (desire to shout all the time), klopemania (synonym of kleptomania), lalomania (desire to speak and speak constantly), orchidomania (obsession with orchids), phytomania (obsession with plants), planomania (anomalous desire to obey social norms), plutomania, polemomania (attraction to war); anglomania, andromania, biblo- 
mania, graphomania, demonomania, erotomania, kinomania, kleptomania, necromania;

2. the ability to form blends with the bases of different origin. For example, as we can see from the above examples, the element-mania can be combined with both Greek-Latin borrowing bases and words of German / Roman / Slavic origin;

3. changing the meaning of an affixoid as compared to a single word, namely, obtaining a broader meaning for the designation of a particular word-forming category. For example, a complex of mania (GreekGreek. $\mu \alpha v i ́ \alpha$ - passion, meaninglessness, craving) may act as part of the name of common psychiatric abnormalities (persecution mania), and as an affixoid meaning "pathological attraction to something, irresistible thirst "with a negative color, for example, fr. and English. oreximania (abnormal thirst for constant eating), trichokryptomania (desire to tear out your own hair), strychninomania (mental deviation due to strychnine poisoning).

Words that contain these elements can no longer be called compound because it is difficult to find a semantically identical syntactic structure (word combination or sentence). But we will not call them simple ones, because we can clearly distinguish several word-elements with some lexical meaning.

Based on all the above-mentioned facts, we can distinguish the following classes of affixoids by origin:

1. Affixoids, which were formed on the basis of the root morpheme due to the high frequency of use, abstraction of a specific lexical meaning, and categorization (Eng. -gate, -friendly, --babble, -man, -like, -berry, -person, -boy, - wise, -head, -ware, -speak, -hop, -monger, -style, -type, -mock, -intensive, -rich, -proof, -free; $\mathrm{Fr}$-clé, -pilote, -limite,-standard, -type, -modèle, -doctoir, -miracle, -vedette, -record, -plafond, -plancher, -limite, -suicide, -espion, -bidon, -charnière, -drapeau, -phare, -éclair, -fleuve, -fantoche, -maison;

2. International affixoids, namely elements of Greek and Latin origin, which are primarily used for term formation: Eng. and fr. -phobia -philie, -mania, -logy / logie, -therapy /-thérapie, mini-, maxi-, midi-, retro-, -pseudo, -graphy/-graphie, -craty/-cratie, -scopy / - scopie, geo-/géo-, bio-, zoo-, psycho-, techno-, -pathy/-pathie, -drome; 
3. Borrowed elements that acquire affixoid status in recipient languages, for example, fr. -club, -maker, -man, -art-, -tour, -ball, -show, -business-, $-n e t, C D-$ (borrowed from English).

\section{Conclusions}

In modern word-building the tendency to affixoidation is observed, compound words are built on the basis of existing sentences and word-combination, but according to the already existing word-building patterns just by adding root morphemes. And this pecularity makes these morphemes close to affixes.

Affixoids, as word-units of intermediate (marginal) status, have the following significant characteristics: productivity, ability to express some specific lexical meaning, possibility to develop some abstract meaning, referring the object to a certain class or a sub-class, ability to be combined with different word-building elements.

In modern linguistics there are alternative variants for nomination of such element: semi-affixes, combining forms (forms which are combined), suffixed elements, half-free morphemes, bound morphemes, word-building elements of the special status, subaffixes, form, which can be combined. One of the founders of the theory of affixoids (semi-affixes) was M. D. Stepanova, who identified the main features of these word-forming constructs: 1) designation of a certain word-forming category; 2) high productivity; 3) functional closeness to real affixes, because of the development of a new generalizing meaning.

Making new words with the help of affixoids is getting more and more productive, so new words are built by means of quasi-compositon, because new lexical units are not built on the basis of the existing sentences and word-combinations (units of the syntactical level of language). This method of word-building become very popular not only in English and French, but also in Slavonic languages that may become the material for future linguistic research, as word-building systems of modern languages are characterized by tendencies to economizing language efforts.

The same tendency may help to explain the appearance of occasional lexical units wich have been created with the usage of affixoids, this direction of research can also be very promising, as occasional words appear every day. 


\section{References:}

1. Bartkov B.I. (1978). O statuse slovoobrazovatel'nykh morfem tipa -smith, -proof, -tight $\mathrm{v}$ angliyskom yazyke [About the status of word-building morphemes -smith, -proof, -tight in English]. Slovoobrazovanie i ego mesto v kurse obucheniya inostrannomu yazyku, no. 6, pp. 42-51.

2. D'yachkova E.S. (2011). Polusuffiksy i obrazovaniya s nimi v sovremennom angliyskom yazyke [Semi-suffixes and new words with them in the modern English language ] ( $\mathrm{PhD}$ Thesis). Barnaul: Barnaul State Pedagogical University.

3. Zacnyj Ju.A. (1999). Rozvytok slovnykovogho skladu anghlijsjkoji movy $v 80$ ti 90-ti roky XX stolittja [The development of English vocabulary in the 1980s and 1990s of the XXc], (PhD Thesis). Kyiv: Kyiv University named after T.H. Shevchenka.

4. Klymenko N.F. (2008). Dyferencijni ta integhracijni procesy v leksyci ta slovotvori suchasnoji ukrajinsjkoji movy [Differentiating and integrating processes in Ukrainian lexics and word-building]. Movoznavstvo, no. 2-3, pp. 136-147.

5. Kubryakova E.S. (1977). Semantika sintaksisa i nekotorye problemy teoriii slovoobrazovaniya [Semantics of syntacsis and som problems of word-building theory]. Sbornik nauchnykh trudov Moskovskogo gosudarstvennogo instituta inostrannykh yazykov im. Morisa Toreza, no. 112, pp. 123-133.

6. Levkovskaya K.A. (1955). Retsenziya na knigu M. D. Stepanovoy [Review of the book by M. D. Stepanova]. Voprosy yazykoznaniya, no. 1, pp. 146-150.

7. Lopatin V.V. (1973). Rozhdenie slova. Neologizmy i okkazional'nye slova [Birth of a word. Neologisms and occasionalisms]. Moskva: Nauka. (in Russian)

8. Motashko V.P. (1984). K voprosu o nominativnykh yazykovykh edinitsakh neopredelennogo slovoobrazovatel'nogo statusa (na materiale novoobrazovaniy frantsuzskogo yazyka) [About the question of nominative unite of indefinite word-building status (on the material of French)]. Novye yavleniya i tendentsii vo frantsuzskom yazyke, no. 1, 59-75.

9. Ryazanov V.Yu. (2000). Osobennosti sinkhronnykh svyazey slovoslozheniya $i$ affiksatsii $v$ sovremennom angliyskom yazyke [Peculiarities of synchronic links of word-building and affixation in English]. (PhD Thesis). Moskow: Moscow Pedagogical State University.

10. Safin R.A. (1974). Status morfem tipa grapho- i -logy [Status of morphemes such as grapho- and logy-]. Voprosy terminologii $i$ lingvisticheskoy statistiki [Questions of terminology and linguistic statistics]. Voronezh, pp. 48-54.

11. Selivanova O.O. (2010). Linghvistychna encyklopedija [Linguistic encyclopaedia]. Poltava: Dovkillja-K. (in Ukrainian)

12. Stepanova M.D. (1953). Slovoobrazovanie sovremennogo nemetskogo yazyka [Word-building of modern German]. Moskow: Izdatel'stvo literatury na inostrannykh yazykakh. (in Russian)

13. Khmelik L.Ya. (1974). Kombiniruyushchaya forma $v$ sisteme sredstv angliskogo slovoobrazovanii [Combining forms in the system of English wordbuilding]. (PhD Thesis). Kyiv: Kyiv University named after T.H.Shevchenko.

14. Shanskiy N.M.(1972). Leksikologiya sovremennogo russkogo yazyka: uchebn. posobie [Lexicology of modern Russian]. Moskow: Prosveshchenie. (in Russian) 
15. Antrushina G.B.(1989). English Lexicology. Moskow: Drofa.

16. Dubois J. (1962). Etudes sur la derivation suffixale en français modern et contemporain. Paris.

17. Ekkehard Z. (1989). Homonymie und Polysemie im allgemeinen einsprachigen Worterbuch Worterbucher. Ein internationales Handbuch zur lexikographie. Erster Teilband. no 5, pp. 779-787.

18. Henzen W. (1947). Deutshe Wortbildung. Tứblinge: Max Niemeyer.

19. Marchand H. (1960). The Categories and Types of Present-Day English Word-Formation. Wiesbaden: O. Harrassowitz.

20. Mitterand H. (1992). Les Mots Franḉais. Paris: Presses Universitaires de France.

21. Nesfield J.C. (1998). Manual of English Grammar and Composition. London: Macmillan.

22. Stekauer P. (2005). Hand-book of Word-Formation. Springler. 